TECHNICAL SCIENCES AND TECHNOLOGIES

UDC 624.01

DOI: $10.25140 / 2411-5363-2019-3(17)-75-81$

\author{
Peter Marcinko, Martin Kočan
}

\title{
THE REVIEW FOR IMPLEMENTATION OF SIMPLE 3D PRINTERS TO EDUCATIONAL PROCESS
}

Urgency of the research. Interest in this topic is aroused, because students are using $3 D$ modelling programs and they can then print and assemble their models during the lessons and verifying some parameters during printing or compare models after.

Target setting. The main goal is to implement $3 D$ printing with a learning process and to acquaint students with $3 D$ printing technology and materials used in this sector. These printers should be used by students on lessons to create $3 D$ objects. Then students create functional assemblies of these objects.

Actual scientific researches and issues analysis. In the past few years there has been rapid use of $3 D$ printing. Many $3 D$ printers have gone through various modifications. This is a modification of the construction site. Various types of printers started to be used, such as Cartesian 3D printers, but also printers that use parallel kinematic structure. Many changes have also been made to the electronic site. Whether they are 8 or 32 bit controllers.

Uninvestigated parts of general matters defining. This article focuses on analysis of $3 D$ printers, technology and materials in $3 D$ printing, features and use in the educational process.

The research objective. The aim of the research is to design and assembly workplace with $3 D$ printers for educational process. Students at this workplace can experimentally use these printers. In the future, these printers could be upgraded and using the Arduino or Raspberry Pi system, could measure some of the printer's features directly in the printing process. These electronic components should be used, for example, to measure moisture, which significantly affects the quality of the print and the filament.

The statement of basic materials. The analysis consists of basic information about $3 D$ printer technologies. The definition of this problem is described below. Based on this knowledge and next information about some 3D printers, was chosen one of these.

Conclusions. Our vision is to implement knowledge about $3 D$ printing into the learning process so that students can not only create objects using $3 D$ modelling programs, but also realize this knowledge. This way they will prove $3 D$ technology, which is fast moving nowadays. By further research in this area we would like to set up a $3 D$ centre for these technologies, where other systems would verify the properties of the printing itself.

Keywords: printers; materials; technology; educational process; parameters.

Fig.: 7. References: 12

Problem definition. In the mid-1990s, the world economy became a revolutionary situation. Companies began to fight for consumer goods. Monotonous production has ceased to win millions of orders. This opened up the era of small-scale production. During this period, equipment became increasingly popular, capable of producing various types of models at minimal cost. However, many of them remained in the manufacturing sector, but the rapid development of individual departments resulted in the emergence of volume printing office printers - so the history of 3D printing began.

The first 3D prototype machine was a machine that utilized stereolithography (SLA) technology, developed and patented by Charles Hull in 1986 in the United States. This machine has not yet resembled modern 3D printers, but it is this invention that defined how a 3D printer works: it builds objects in layers. Hull created the company 3D Systems, which produced the first bulky printing device called Stereolithography Apparatus. The first model of this machine, which had a wide spread, developed in 1988, SLA-250.

In 1990 a new method of model production was used - the fixation method. This method was developed by Scott Crump, the founder of Stratasys, and his wife, who continued to develop 3D printing together. The modern historical phase of 3D printing began in 1993 with the creation of Solidscape. In 1995, two students from the Massachusetts Institute of Technology modified the inkjet printer, but in special containers, these images were already cubic, and at the same time the concept of 3D printing and the first 3D printer appeared.

The history of creating a 3D printer continues with the advent of a technology called PolyJet, which is based on the use of photopolymer liquid plastic. With this method, the print head „draws" a photopolymer layer that is immediately irradiated with a lamp. The method has proven to be advantageous in many respects: its cost is significantly lower, and the high precision of production provides the opportunity not only for models but also for ready-to-use parts.

Over time, the development of 3D printing has greatly accelerated: the use of new materials and foundations, the dimensions and cost of the devices have decreased. The first 3D

(C) Пітер Марцінко, Мартін Кочан, 2019 
TECHNICAL SCIENCES AND TECHNOLOGIES

printers were huge, but now they are also suitable for the desk (except industrial 3D printers). A modern three-dimensional printer is increasingly similar to an ordinary printer that prints images on paper. At the beginning of the development, the price of a single printer was only available to very large companies, but now anyone can buy a 3D printer. On average, the price of one model is more than 200 euros. The history of the $3 \mathrm{D}$ printer is not yet over and the most interesting is waiting for us in the near future [1].

3D printing technology. The basic principle is additive manufacturing, which in practice means that we do not have a large block of material at the beginning, but printing begins on a clean surface by gradually applying the material in individual layers as precisely as possible. In this way, the printer prints the material in portions in 2D space. Subsequently, it is moved horizontally by another layer until a complete 3D model is created. Although the individual printing methods differ from one another, the application of the material layer by layer all have in common.

Therefore, the 3D model (most often in STL format) needs to be "cut" in the software (slicer) before printing, which will be divided by several thin layers forming the whole object. The layer thickness corresponds best to the model quality. The thinner the layers, the more precise the print quality. Printing in the very least layers therefore seems to be the best quality, but has its limitations. The hardware itself has limits on how thin it can create. Even if the hardware allows extremely thin layers, we waste a lot of time in software that has the model cut into many layers. The printing time itself is also considerably extended, since it takes longer to create one layer and at the same time to create multiple layers [2].

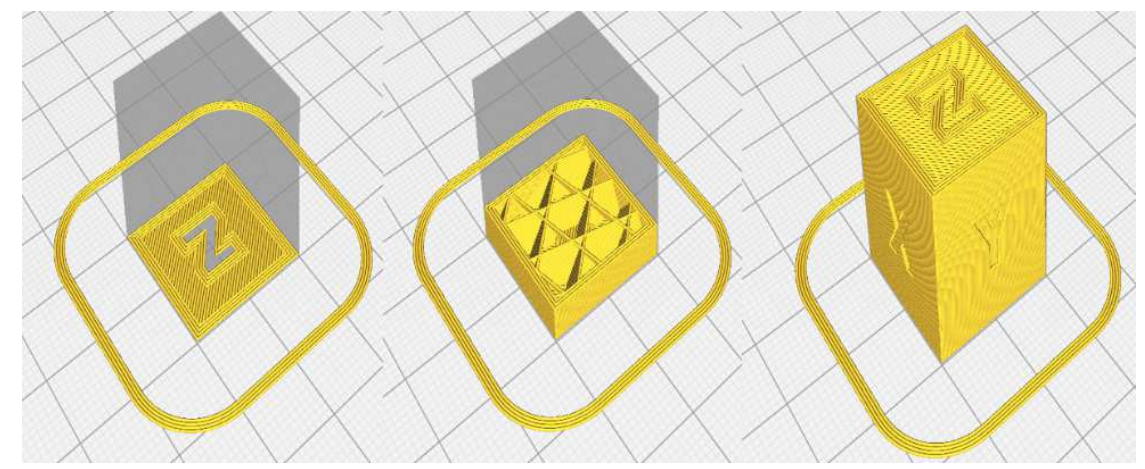

Fig. 1. Calibration cube in layers

Types of 3D technology. FDM/FFF printers are the most commonly Cartesian type of printers. Cartesian refers to the coordinate system used by the printer to move the print head and the build plate. In these printers, there are three rails corresponding to each axis (X, Y, \& Z).

Firstly, the raw material, filament, is fed into the extruder. FDM/FFF printer filaments are available in two different diameters, $1.75 \mathrm{~mm}$ which is the most common type and $2.85 \mathrm{~mm}$. A particular printer uses only one type of filament. The gear mechanism in the extruder pulls the filament and pushes it down to the heater, where the filament gets melted. The melting temperature depends on the type of filament used and generally ranges from $190^{\circ} \mathrm{C}$ for PLA to $300^{\circ} \mathrm{C}$ for polycarbonate. This melted filament then flows to the nozzle.

The nozzle is generally available in multiple diameters $(0.2$ to $1 \mathrm{~mm})$. The nozzle diameter can affect the layer thickness and the print quality. The nozzle deposits the material onto the build platform in the appropriate geometry as per the model to be printed. The nozzle moves in X \& Y direction and deposits the first layer of the print. Once the first layer is completely deposited, the build platform drops down by a small amount equal to the layer thickness and the printing again starts for the second layer. This time the first layer and the second layer are still hot and as a result, they fuse together for a strong bond. This process continues till the complete object is printed.

After printing, the object can be easily removed by hand or with a simple scrapper. The FDM/FFF printed parts have visible layer lines and are generally very coarse. It can be further 
TECHNICAL SCIENCES AND TECHNOLOGIES

post-processed by sanding, polishing, priming \& painting, acetone vapour smoothing, electroplating, etc.

The accuracy of FDM/FFF printers is least in comparison with the other technologies. It is dependent on the minimum distance vertical distance the bed (nozzle in some cases) can travel. Minimum the distance better will be the accuracy. The accuracy also depends on various other factors like the filament, layer thickness, speed, and other parameters set while slicing the object.

FDM/FFF printed parts are mostly recommended to be used for Form and fitment testing, jigs \& fixture, and most industrial usage for prototyping. The parts have good dimensional accuracy but are aesthetically very coarse [3].

SLA - Stereolithography is an additive manufacturing technique that works by targeting a UV laser to a bath filled with a photosensitive resin. Points that are generated from 3D data are used to focus the laser. The photosensitive polymers cure under the influence of ultraviolet light, forming layer-by-layer the desired part. Stereolithography requires the use of support structures that are anchored to the lifting platform to prevent deformation. It makes it possible to build large parts with very high precision, attention to detail and excellent surface finish. A wide range of materials allows to build parts with specific properties [4]. Often use materials: Protogen 18420, NeXt, NanoTool etc. The disadvantages is higher price of the printer and materials.

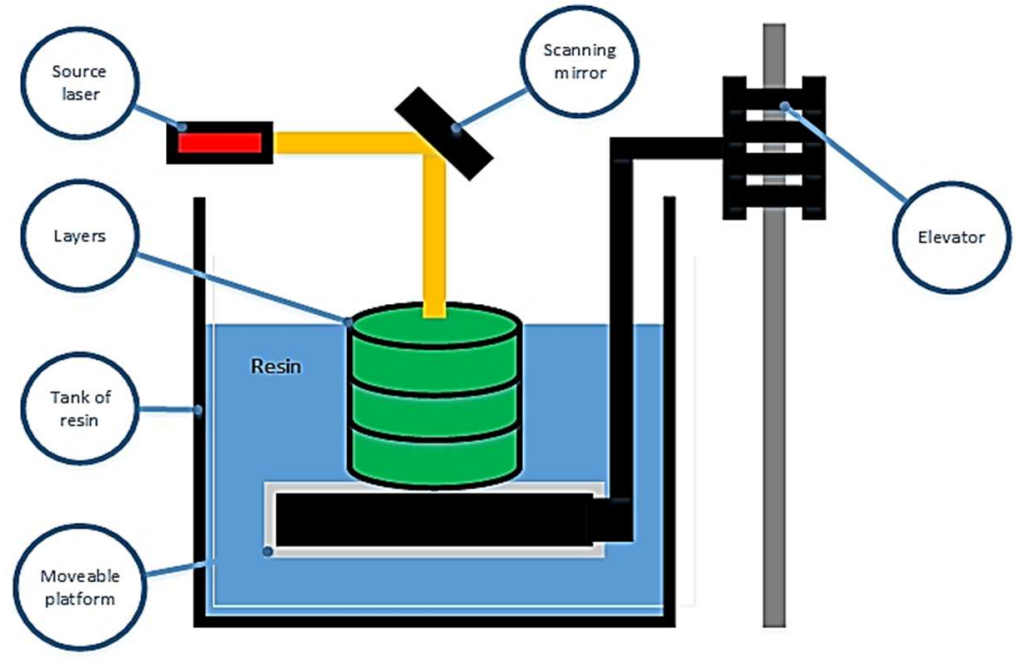

Fig. 2. Sterolitography printer (SLA)

Other methods include: SLS, DMLS, EBM or SLM. These methods are different from FDM and SLA in that the material used is powder. SLS applies a thin layer of the powder on platform. The powder is thermoplastic [5]. All layers are irradiated with a laser. This method can work with various materials which are in the form of a powder, e.g. ceramics, plastics, etc. Other methods are DMLS and EBM. DMLS also has the same principle as SLS, but it is dedicated to metals and their alloys. EBM uses an electron beam to melt the material. It is used for dense objects made of titanium, cobalt and chrome. SLM is an energy process because the laser produces heat for each layer that exceeds the melting point of the material. Objects are extremely rigid. SLM uses only some materials, e.g. steel, titanium, cobalt, aluminium, copper, tungsten and chrome [6].

Materials for 3D printing. Polylactide (PLA) - one of the most widely used thermoplastics. This material is a lactic acid polymer, causing PLA to be a fully degradable material. The raw material for the production of polylactide is corn and cane. We can say that the environmentally friendly material of the material has been reflected in its longevity. Plastic easily absorbs water and is relatively softer.

Usually PLA models are not intended for functional use, but serve as design models, souvenirs and toys. Among some practical industrial applications, we can mention the production of packaging for food products, medicament containers and surgical fibers, as well as applications in bearings that do not have a high mechanical load (for example in modeling), which is possible due 
TECHNICAL SCIENCES AND TECHNOLOGIES

to the excellent material slip coefficient. for use in 3D printing, the low melting temperature is only $170-180^{\circ} \mathrm{C}$, which contributes to low energy consumption and the use of cheaper brass and aluminum nozzles. Typically, the extrusion is carried out at a temperature of $160-170{ }^{\circ} \mathrm{C}$.

At the same time, the PLA solidifies slowly (the solidification temperature is about $50{ }^{\circ} \mathrm{C}$ ), which should be taken into account when selecting a 3D printer. The best option is a device with an open cover, heated work platform (to avoid distortions of large models) and with optional fans to cool the fresh layers of the model.PLA has a low shrinkage, ie a loss of volume during cooling, helping to prevent deformation. Nevertheless, shrinking has a cumulative effect as the size of printed models increases. In the latter case, it may be necessary to heat the work platform to cool the printed objects evenly [7].

Akrylonitril Butadien Styren (ABS) plastic is characterized by extraordinary strength and toughness, has high impact and shock resistance (even at low temperatures), resistance to crack propagation and abrasion. It also withstands adverse weather conditions and UV radiation. ABS has a very low thermal conductivity, so there is no need for additional insulation. Due to its chemical resistance, plastic does not mind salts, while concentrated acids, strong alkalis, organic solvents and aromatic hydrocarbons can harm it. ABS is non-absorbent and harmless to health. Styrene gives the plastic a glossy and impermeable surface. Polybutadiene is a rubbery substance and provides ABS elasticity even at low temperatures [8].

Another material for 3D printing is High Impact Polystyrene (HIPS), used as a backing material for ABS. For this printing, it is necessary to have 2 extruders. first for construction material and second for support material. Polyvinyl alcohol (PVA) is also used as a support material, but it can be easily dissolved in water and the HIPS material using only a solvent. We also know materials like Nylon, Polycarbonate (PC), wood-like material and many others [9].

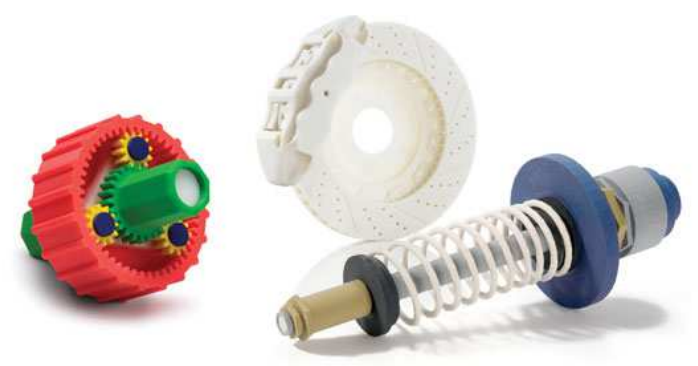

Fig. 3. Filaments for $3 D$ printing and some models

Proposed 3D printers. Of the many types of printers, three were considered. The first printer was Anet A8. Anet A8 is a complete printer that lets you turn ideas from paper into reality. Its great feature is that it can provide printing accuracy of much more expensive devices and is also suitable for home and educational use. Other advantages of this printer include the ability to print from a variety of materials, although it works best with PLA and ABS materials. The price of this printer is around $130 €$. Fig. 4 shown this $3 \mathrm{D}$ printer [10].

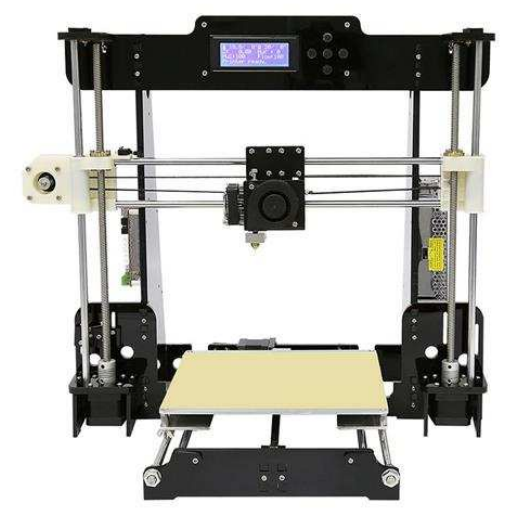

Fig. 4. Anet A8 
TECHNICAL SCIENCES AND TECHNOLOGIES

The second printer is the 3D printer Tevo Tarantula. Inspired by the Prusa $\mathrm{I} 3$ printer, whose popular, proven design has fallen in love with thousands of people around the world. Tarantula is part of the RepRap project and all parts are open source. This means that the printer is designed from readily available parts and parts. The construction of the printer is made of extruded aluminium frame with a black finish. This is complemented by acrylic connecting parts. Quiet and smooth operation of the printer is ensured by laser-cut metal parts of moving parts, bearings and wheels. The Tarantula comes with a heated aluminium print pad of $200 \mathrm{~mm}$ x $200 \mathrm{~mm}$ for better filament attachment. The price of this printer is around $250 €[11]$.

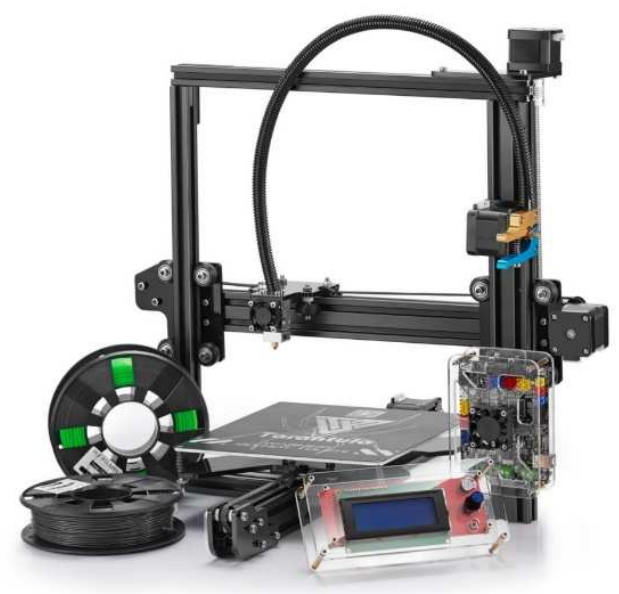

Fig. 5. Tevo Tarantula

The last printer to be selected is Ender 3. This printer also supports FDM technology. It also supports printing with PLA, ABS, etc. The size of the object can be up to $220 \times 220 \times 250 \mathrm{~mm}$. It has a relatively compact and very robust shape. The price is around $220 €$.

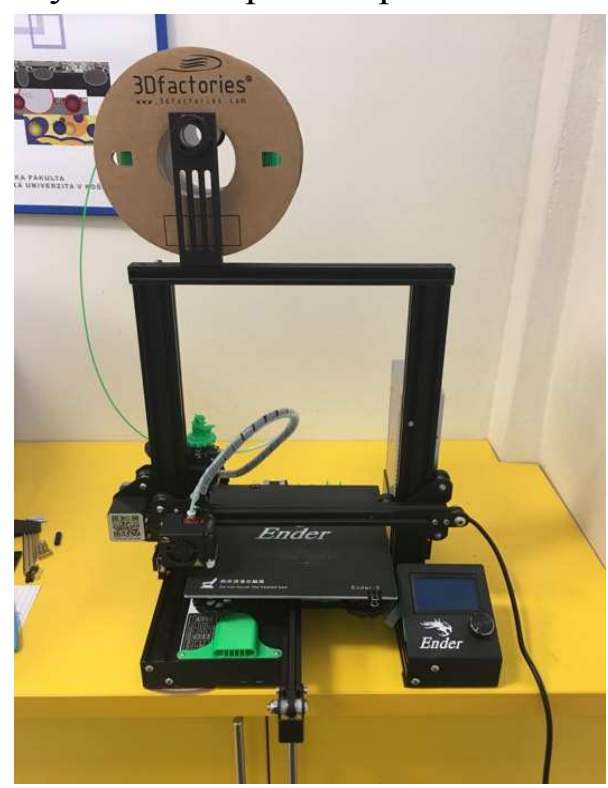

Fig. 6. Ender 3

Among these printers, Ender 3 was chosen. The other two are also come into consideration in the future. It was chosen for its compact solution. It should serve as a teaching equipment students learn the basics of modelling in multiple programs, e.g. Creo, SolidWorks, and Autodesk Inventor. Based on their knowledge of these programs, they would like to show them how to work with this type of 3D printer technology. They also want to be able to not only design their final thesis, but also print them out and then assemble them. 


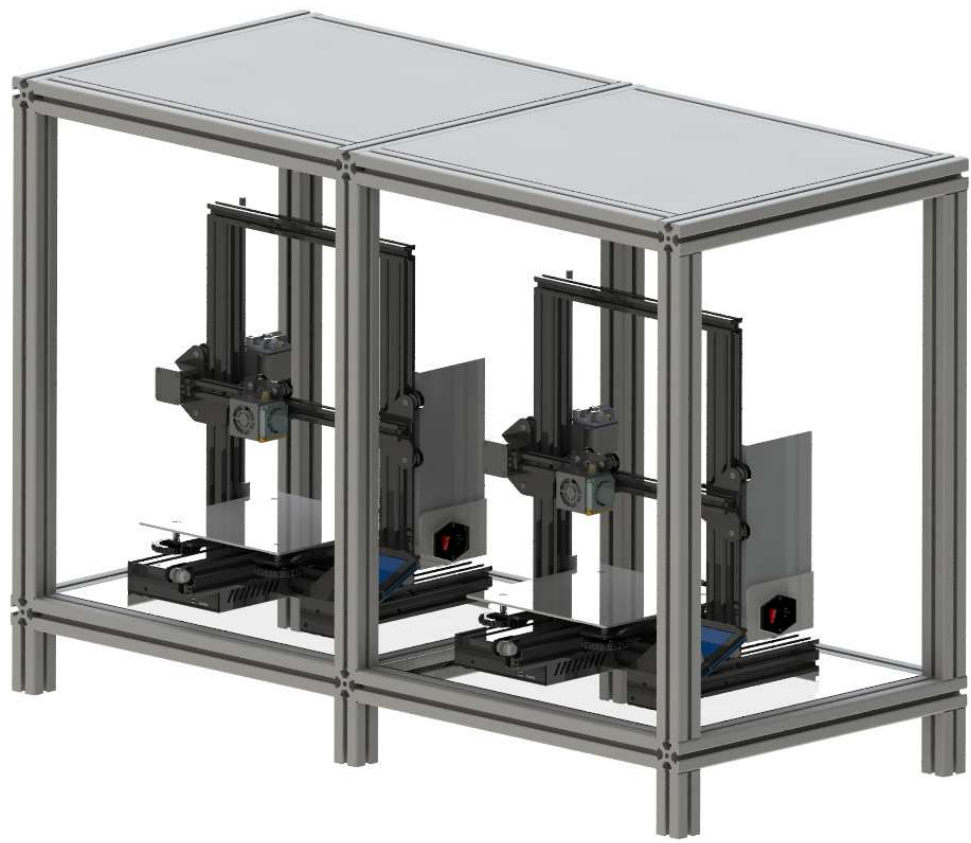

Fig. 7. Box with $3 D$ printers

In the next period, the lessons will focus more on $3 \mathrm{~d}$ printers. 3D printers have made great progress in recent years and many people buy them home as a hobby. Countless objects can be printed on these devices. Therefore, there should not be only one printer, and therefore in the future it would be necessary to buy several printers, which the students folded and subsequently could use. In addition to modeling in $3 \mathrm{D}$ environments, the lessons could also focus on the programs that use these printers. These are so-called slicer programs, e.g. Cura, IdeaMaker, Repetier, OctoPrint, Slic3r, Simplify3D and many more [12]. So after creating a 3D model, whether it is a single part or the whole assembly, these objects could then be implemented in the program slicer. In these programs, students would try different parameters to adjust the quality of the printed object. It would be mainly to choose the right layer from which the object will be printed and also to set the right print speed.

Conclusions. This article describes the basic technologies used in 3D printing. It introduces the materials used in printing. The aim is to acquaint students with the possibilities of 3D printing. In the future, it would be necessary to purchase several printers that use different types of technology to experience the development process practically. From the design of the part in the modeling program to its production - printing. This printer is sufficient, but it needs some improvements that will have to be done to make it better.

\section{Acknowledgements}

This research was funded by Slovak Grant Agency VEGA 1/0389/18 "Research on kinematically redundant mechanisms".

\section{References}

1. História vývoja $3 D$ tlače. Retrieved from https://xyzprint.eu/aktuality/historia-3d-tlace.html.

2. Úvod do $3 D$ tlače. Retrieved from https://portal.fmed.uniba.sk/download.php?fid=575.

3. How FDM/FFF 3D Printing Technology Works? Retrieved from https://manufactur3dmag.com/ working-fdm-fff-3d-printing-technology.

4. Stereolitografia. Retrieved from http://www.sethal.sk/technologia/sla.

5. Laser sintering, melting and others $-S L S$, SLM, DMLS, DMP, EBM, SHS. Retrieved from https://www.additive.blog/knowledge-base/3d-printers/laser-sintering-melting-sls-slm-dmls-dmp-ebm-shs.

6. FAQ - vysvětlení DMLS, SLS, SLM, EBM, Laser Cusing. Retrieved from http://www.innomia. cz/faq-vysvetleni-dmls-sls-slm-ebm-laser-cusing. 
TECHNICAL SCIENCES AND TECHNOLOGIES

7. Materály pre tlač na 3D tlačiarni metódou vrstvového natavenia (FDM/FFF). Retrived from https://xyzprint.eu/aktuality/co-je-potrebne-vediet-o-plaste-typu-ABS-PLA.html.

8. Rozdiel medzi PLA a ABS. Retrived from https://tvaroch.sk/blog/rozdiel-medzi-abs-pla.

9. 3D Printer Materials Guide: 3D Printing Plastics. Retrieved from https://www.3dnatives.com/ en/plastics-used-3d-printing1 10420174.

10. 3D tlačiarě̆ Anet A8 nebola nikdy takto lacná! Retrieved from https://vosveteit.sk/3dtlaciaren-anet-a8.

11. 3D tlačiaren̆ Tevo Tarantula. Retrieved from https://www.roboking.sk/products/3d-tlaciarentevo-tarantula?variant $=12973115277354$.

12. Top 10 Best Slicer Software For All Levels. Retrieved from https://www.3dnatives.com/en/top10-slicer-software-200520194.

UDC 624.01

\section{Петер Мариинко, Мартин Кочан \\ ОГЛЯД 3 МЕТОЮ ВПРОВАДЖЕННЯ ПРОСТИХ 3D ПРИНТЕРІВ У НАВЧАЛЬНИЙ ПРОЦЕС}

Актуальність теми дослідження. Зростаючий інтерес до иієї теми викликаний тим, що студенти використовують програми $3 D$ моделювання і можуть друкувати та збирати свої моделі під час занять, а також контролювати деякі параметри впродовж друку або порівнювати моделі після друку.

Постановка проблеми. Головною метою було впровадження $3 D$ друку в навчальний процес $і$ ознайомити студентів із технологією $3 D$ друку та матеріалами, щңо застосовуються в иьому процесі. Такі принтери мають використовуватися студентами на заняттях для створення 3D об'єктів. Далі студенти можуть створювати з них функиіональні збірки.

Аналіз останніх досліджень і публікацій. Протягом останніх декількох років спостерігається бурхливе використання 3D друку. Багато 3D принтерів вийшли з використання через різні модифікації. Це зміни, щео стосуються конструктивної будови. Почали використовуватися різноманітні типи принтерів, зокрема картезіанські $3 D$ принтери, а також принтери, щцо мають паралельну кінематичну конструкцію. Багато змін також відбулося в електронній будові. Поки щзо вони використовують 8- або 16-бітні контролери.

Виділення недосліджених частин загальної проблеми. Ця стаття присвячена аналізу 3D принтерів, технолоzії та матеріалів у 3D друиі, особливостям та використанню ї у навчальному процесі.

Постановка завдання. Метою дослідження була розробка та складання робочого місия з $3 D$ принтерами для навчального процесу. Студенти на цььому робочому місиі можуть експериментально використовувати иі принтери. Надалі иі принтери можна буде оновлювати та з використанням систем Arduino або Raspberry Pi з'явиться можливість вимірювати деякі параметри принтера безпосередньо в процесі друку.

Виклад основного матеріалу. Аналіз складається з основної інформачії про технології $3 D$ друку. Формулювання иісї задачі описано нижче. На основі цих знань та наступної інформачії про деякі $3 D$ принтери було обрано один із них.

Висновки відповідно до статmі. На наш погляд, впровадження знань про ЗD друк у навчальний прочес повинен відбуватися так, щцоб студенти могли не лише створювати об'єкти з використанням програм 3D моделювання, а також реалізувати ці знання. Таким чином вони зможуть удосконалювати $3 D$ технології, ццо стрімко розвиваються в наш час. У подальших дослідженнях у цьому напрямку планується створити $3 D$ центр технологій, в якому інші системи будуть самостійно перевіряти властивості друку.

Ключові слова: принтери; матеріали; технології; навчальний процес; параметри.

Puc.: 7. References: 12.

Peter Marcinko - PhD student, Technical University of Kosice (Letna 9, 04200 Kosice, Slovak Republic).

Пітер Марцінко - аспирант, Технічний університет Кошице (Letna 9, 04200 Košice, Slovak Republic).

SCOPUS Author ID: 57200138054

E-mail: peter.marcinko@tuke.sk

Martin Kočan - PhD student, Technical University of Kosice (Letna 9, 04200 Kosice, Slovak Republic).

Мартін Кочан - аспирант, Технічний університет Кошице (Letna 9, 04200 Košice, Slovak Republic).

E-mail: martin.kocan@tuke.sk 